\title{
Analysts' Target Prices and Stock Recommendations
}

\author{
Jie Zhou \\ NUS Business School, National University of Singapore \\ 15 Kent Ridge Dr, Singapore, 119245 \\ Tel: 65-6601-1475Ｅ-mail: bizzj@nus.edu.sg
}

Received: November 2, 2012

Accepted: November 15, 2012

Online Published: November 21, 2012

doi:10.5430/afr.v2n1p1

URL: http://dx.doi.org/10.5430/afr.v2n1p1

\begin{abstract}
In this study, I propose a simple framework to examine the link between analysts' target prices and their stock recommendations. I hypothesize that the favorableness of stock recommendations is positively associated with the deviation of the ratio of target price to price from the benchmark return. I employ three widely used models to proxy for the benchmark return: the CAPM, Fama and French (1993) 3-Factor Model and Carhart (1997) 4-Factor Model. I find results consistent with my hypothesis. Both contingency table and regression analysis support the prediction that analysts issue more favorable recommendations to stocks with a higher difference between the ratio of target price to price and the benchmark return. I further investigate whether this positive association is due to analysts' perception about risk or mispricing. I use firm characteristics as the explanatory variables to examine how analysts incorporate them into their outputs. I find evidence that target prices are associated with growth variables the same way as recommendations are. However, I am not able to completely rule out the risk interpretation. Therefore, the mechanism underlying the link between analysts' target prices and stock recommendations is not conclusive.
\end{abstract}

Keywords: Analyst forecast, Target price, Stock recommendation

\section{Introduction}

The ratio of target price to current stock price can be interpreted as the analysts' belief about the expected rate of return and can be directly compared to the firm's required cost of equity capital. Since the required cost of equity capital is an important input for security valuation that forms the basis for stock recommendations, target prices and stock recommendations should be linked in a predictable manner. In this study, I examine the link between analysts' target prices and stock recommendations.

To examine whether target prices and stock recommendations are linked, it is necessary to specify how they might be linked. I propose a simple framework to develop the link. Presumably, analysts use their earnings forecasts along with other information to estimate a stock's value and project the target price based on the market's assessment of risk. The ratio of target price to current stock price, the firm's expected rate of return (viewed by the analysts), is then compared to the market's assessment of return. This comparison forms the basis for the recommendation. That is, buy (sell) recommendations should be observed when the ratio of target price to price exceeds (falls short of) the market's assessment of return. Therefore, I hypothesize that the deviation of the ratio of target price to price from the market assessment of return can explain the cross-sectional distribution of analysts' stock recommendations.

To test the hypothesized association between stock recommendations and target prices, I consider three possible models of the market equilibrium return: the Capital Asset Pricing Model (CAPM) described in Sharpe (1964) and Lintner (1965), Fama and French's (1993) 3-factor model and Carhart (1965) 4-factor model. These models have been widely used in prior studies as proxies for the market equilibrium. Though there is controversy regarding the superiority of one model over the other, it is not the major purpose of this study. Therefore, I report results based on all three models.

I employ contingency table and regression analysis to test my hypothesis. The results are generally consistent with my prediction. In terms of the two-way contingency table, there is a higher proportion of buy recommendations for stocks with the ratio of target price to price exceeding the benchmark return than for stocks with a lower ratio. Moreover, the chi-square statistics is statistically significant at the 0.001 level $\left(\chi_{\mathrm{df}=1}^{2}=388.24 ; \mathrm{p}<0.001\right)$. The mean recommendations support the prediction as well: the mean recommendation for the high ratio portfolio is greater than 
the mean recommendation for the low ratio portfolio and the t-statistics, comparing the difference in means, is statistically significant at the 0.001 level $(\mathrm{t}=30.07)$.

Regression analysis reinforces the results from the contingency table. When CAPM model is used as the proxy for the benchmark return, there is a significant positive coefficient on $\triangle T P P$, measured as the difference between the ratio of target price to price and the benchmark return $(\beta=0.7705 ; \mathrm{t}=3.13)$. The results for other two models generate similar inferences though they are slightly weaker. Overall, the results are consistent with the contingency table analysis as well as the prediction that analysts issue more favorable recommendations to stocks with a higher difference between the ratio of target price to price and the benchmark return.

The positive association between the favorableness of stock recommendations and the deviation of the ratio of target price to price from the benchmark return is consistent with at least two interpretations. One interpretation is that the ratio of target price to price indicates analysts' perception about the firm risk. When analysts perceive the firm to be riskier than what the market perceives to be, they expect a higher return and then are more likely to issue a more favorable recommendation. An alternative interpretation is that the ratio of target price to price reflects analysts' opinion of security mispricing. Therefore a higher (lower) ratio of target price to price may indicate that analysts believe the stock is more likely to be undervalued (overvalued), and hence they issue a more (less) favorable recommendation.

I conduct further analysis to investigate this issue. I examine the extent to which the ratio of target price to price is associated with firm characteristics (Note 1). I first focus on four risk attributes that have been proposed in prior literature: beta, size, book to market ratio and price momentum. I find a positive relation between the ratio of target price to price and market beta $(\beta=0.4467 ; \mathrm{t}=5.50)$ and a negative relation between the ratio of target price to price and firm size $(\beta=-0.0025 ; \mathrm{t}=-10.68)$. The relationship between the ratio of target price to price and book-to-market is insignificant. Inconsistent with risk factor explanation (Carhart 1997), I find a negative relation between the ratio of target price to price and price momentum $(\beta=-0.022 ; \mathrm{t}=-10.26)$.

These results are in line with Brav, Lehavy and Michaely (2005). However, Brav et al. (2005) interpret it as the evidence that the ratio of target price to price reflects the market expectation of return. Since I do not make this assumption, I interpret the results as the evidence that in a risk context, analysts' expected returns are related to their systematic exposure to the market and firm size, which is consistent with the market expectation. However, analysts' perception deviates from the market in terms of the book to market ratio and price momentum.

To examine the extent to which the positive association between the deviation of the ratio of target price to price from the market assessment of return and stock recommendations is due to mispricing, I next focus on eleven mispricing variables that have demonstrated abilities to forecast cross-sectional differences in returns in prior studies. I conduct the analysis by Jegadeesh, Kim, Krische and Lee (2004) (Hereafter, JKKL) for my sample to allow for a direct comparison of information used by analysts to generate target prices and stock recommendations. Since stock recommendation reflects opinions on the relative degree of mispricing (Womack 1996), the study by JKKL serves as a natural benchmark for the comparison. I find that both target prices and stock recommendations seem to favor growth ("glamour") stocks despite their well documented negative association with future returns. The coefficients on three growth variables: sales growth $(S G)$, long-term growth $(L T G)$ and capital expenditure $(C A P E X Q)$ are all positive and statistically significant. Since growth variables are widely considered as market anomaly (La Porta 1996), this evidence suggests that the ratio of target price to price might reflect some dimensions of mispricing as well.

However, they do not agree in all aspects. Specifically, for some valuation signals, price momentum and trading volume variables, target prices and stock recommendations appear to incorporate them in completely opposite directions. This finding suggests that although intuitively target prices should be highly associated with stock recommendations, they likely provide different information to investors. In sum, I am not able to rule out the possibility that the ratio of target price to price also reflects some dimensions of risk.

This analysis raises the concern of correlated omitted variable problems. The positive association between the deviation of the ratio of target price to price from the market assessment of return and stock recommendations might be driven by some other common factors. To alleviate this endogeneity problem, I include all the eleven variables in the main regression and find that the difference between the ratio of target price to price and the market assessment of return continues to explain the stock recommendations. For all three benchmark models I employ, the coefficients on $\triangle T P P$ are all positive and statistically significant. 
This study contributes to the literature in the following aspects. First, this study examines the relation between target prices and stock recommendation. Research establishing the relationships among various analysts' outputs is still limited, with one notable exception being Bradshaw (2004) where he examines the link between earnings forecasts and stock recommendations. This is the first study, to the best of my knowledge, to develop the link between stock recommendations and target prices. Second, I provide some evidence that the ratio of target price to price indicates relative degree of mispricing, suggesting that mispricing might be the mechanism underlying the link between target prices and stock recommendations.

The paper proceeds as follows. Section 2 discusses prior research and develops the hypothesis. Sample selection and descriptive statistics are discussed in section 3. Section 4 presents the contingency table and regression analysis. Section 5 provides further analysis on risk or mispricing explanation. Section 6 concludes.

\section{Related Literature and Hypothesis Development}

\subsection{Prior Literature}

Prior literature mostly focuses on two of the summary elements in security analyst reports: earnings forecasts and stock recommendation. Analysts' earnings forecasts provide information relevant to expectations of future cash flows that are considered as the primary determinants of common stock valuations (Dechow, Kothari and Watts 1998). On the other hand, analysts' stock recommendations reflect opinions on the relative degree of security mispricing (Womack 1996). Bradshaw (2004) examines the link between earnings forecasts and stock recommendations via valuation models and provides little evidence that analysts' recommendations are explained by either residual income model specification.

In contrast, research on analysts' target price has received very limited attention. Notably, Brav and Lehavy (2003) examine short-term market reactions to target price revisions and find a significant market reaction to the information contained in analysts' target prices, conditional on contemporaneously issued stock recommendations and earnings forecasts revisions. Asquith, Mikhail and Au (2005) examine the complete contents of Institutional Investor All-American analyst reports and find that changes in summary earnings forecast, stock recommendations, and price targets all provide independent information to the capital markets. They note that incorporating changes in analyst price targets particularly increases the fit of their regression results. More strikingly, they find that under some circumstances (for example, reiterations), target prices and analysts' justification are the only significant elements.

In addition to the evidence indicating the significant market reaction to analysts' target prices, database also shows that starting from the mid-1990s, a growing number of sell-aside analysts had begun to disclose price targets in their published stock research reports. For example, Using First Call as the primary database for target price, Gleason, Johnson and $\mathrm{Li}$ (2012) document that price target availability increased markedly during their sample period from a low of 11 percent in 1997 to 50 percent in 2003. This evidence indicates that target price has indeed become a more and more important output analysts produce.

Despite the growing popularity of target prices and their potential to provide a more precise investment signal, surprisingly little is known about how target prices relate to the other two outputs analysts produce. What evidence we do have is primarily descriptive. For example, Schipper (1991) contends that analysts' ultimate task is to issue stock recommendations while forecasts and target prices are merely supporting input factors. Focusing on target prices, Bradshaw (2002) analyzes reports for a random sample of 103 companies and finds that the incidence of target prices being included in the report is increasing with the favorableness of the stock recommendation. He argues that analysts issue target prices mainly to justify their stock recommendations.

\subsection{Hypothesis Development}

Evidence linking target price to stock recommendation is very limited so far. This study attempts to fill this void. Schipper (1991) argues that stock recommendations consider whether the expected return implied in the difference between target price and current stock price exceeds the firm's required cost of equity capital. If so, then target prices and stock recommendations should be related in a predictable manner. In this paper, I explicitly examine the association between target prices and stock recommendations.

To this end, I propose a simple framework to develop the link between analysts' target prices and stock recommendations. Presumably, analysts use their earnings forecasts along with other information to estimate a stock's value $V$. Regardless of the underlying valuation model that analysts might adopt (Note 2), $V$ could be written as: 


$$
V=f(\Omega)
$$

where $\Omega$ represents the information set that analysts use in estimating the stock value. It includes all public signals and possibly analyst's own private information.

If the analyst believes the underlying stock price should be $V$, then he will accordingly set his target price $T P$ (Note 3 ) as:

$$
T P=V *(1+r)
$$

where $r$ is the market's assessment of a firm's risk (Note 4).

Admitting the possibility that prices can deviate from intrinsic values, analysts' stock recommendation reflects opinions on security mispricing. Let $P$ be the underlying current stock price, then a rational analyst will issue the stock recommendation according to the following algorithm (Note 5):

$$
\begin{aligned}
& \frac{V}{P}>1 \Rightarrow \text { Buy } \\
& \frac{V}{P}=1 \Rightarrow \text { Hold } \\
& \frac{V}{P}<1 \Rightarrow \text { Sell }
\end{aligned}
$$

Divide both sides of equation (1) by current stock price $P$ :

$$
\frac{T P}{P}=\frac{V}{P} *(1+r)
$$

The above equation suggests that there is a link between analysts' target prices and stock recommendations. Specifically, when the ratio of target price to price exceeds the market equilibrium return, analysts will issue a "buy" recommendation; when the ratio of target price to price equals the market equilibrium return, analysts will issue a "hold" recommendation; analysts will issue a "sell" recommendation otherwise.

Based on the discussion above, I hypothesize that:

H1: The favorableness of analysts' stock recommendations is positively associated with the degree that the ratio of target price to price deviates from the market assessment of return.

\subsection{Benchmark Return}

To test the hypothesis, I need a proxy for the market assessment of return. I employ three market equilibrium models: the Capital Asset Pricing Model (CAPM) described in Sharpe (1964) and Lintner (1965), Fama and French (1993) 3-factor model, and Carhart (1997) 4-facotr model. This section briefly describes these models.

\section{The Capital Asset Pricing Model (CAPM)}

First, I employ the theoretical framework of the Capital Asset Pricing Model (CAPM) and estimate the following monthly time-series regression:

$$
r_{i t}=\alpha_{i}+\beta_{i} R M R F_{t}+\varepsilon_{i t}
$$

where $r_{i t}$ is the return on the common stock of firm $i$ for month $t$; RMRF is the excess return on a value-weighted aggregate market proxy.

This test yields parameter estimates of $\alpha_{i}$ and $\beta_{i}$.

\section{3-Factor Model}

Fama and French (1993) identify three common risk factors that can explain the cross-section of average return: one overall market factor and factors related to firm size and book-to-market equity. Following Fama and French (1993)'s 3-factor model, I estimate the following monthly time-series regression:

$$
r_{i t}=\alpha_{i t}+\beta_{i t} R M R F_{t}+s_{i t} S M B_{t}+h_{i t} H M L_{t}+\varepsilon_{i t}
$$

where $r_{i t}$ is the return on the common stock of firm $i$ for month $t$; $R M R F$ is the excess return on a value-weighted aggregate market proxy; and $S M B$ and $H M L$ are returns on value-weighted, zero-investment, factor mimicking portfolios for size and book-to-market equity. 


\section{4-Factor Model}

Carhart (1997) constructs a 4-factor model using Fama and French's (1993) 3-factor model plus an additional factor capturing Jegadeesh nd Titman's (1993) one-year momentum anomaly. The 4-factor model is consistent with a model of market equilibrium with four risk factors. Alternatively, Carhart (1997) interprets it as a performance attribution model, where the coefficients and premia on the factor-mimicking portfolios indicate the proportion of mean return attributable to four elementary strategies: high versus low beta stocks, large versus small market capitalization stocks, value versus growth stocks, and one-year return momentum versus contrarian stocks. Specifically, I estimate the following monthly time-series regression:

$$
r_{i t}=\alpha_{i t}+\beta_{i t} R M R F_{t}+s_{i t} S M B_{t}+h_{i t} H M L_{t}+p_{i t} M O M_{t}+\varepsilon_{i t}
$$

where $r_{i t}$ is the return on the common stock of firm $i$ for month $t$; RMRF is the excess return on a value-weighted aggregate market proxy; and $S M B, H M L$, and $M O M$ are returns on value-weighted, zero-investment, factor mimicking portfolios for size, book-to-market equity, and one-year momentum in stock returns (Note 6).

\section{Sample Selection and Descriptive Statistics}

\subsection{Sample Selection}

I construct my sample as follows. I obtain my analyst consensus price target forecast data from the I/B/E/S Detail File for the period 2000 through 2009. In addition, I also require consensus data on analyst recommendations. I obtain analyst recommendations from the $\mathrm{I} / \mathrm{B} / \mathrm{E} / \mathrm{S}$ Recommendations database. $\mathrm{I} / \mathrm{B} / \mathrm{E} / \mathrm{S}$ codes recommendations into five ordered categories: strong buy $=1$; buy $=2$; hold $=3$; sell $=4$; and strong sell $=5$. For a more intuitive interpretation of my results, I reverse this coding. For each calendar quarter, I obtain the consensus recommendation level issued in the most recent month. For each observation, I require that the firm's market price information be available in the CRSP database. I delete observations with stock price less than $\$ 1$ to control the outliers. I delete some irregular data (e.g., the mean target price is 0 ). Finally, I truncate my sample at the $1 \%$ and $99 \%$ to delete extreme observations. The full sample contains 109,230 firm-quarter observations.

The second set of sample firms is constructed from the full Sample and is used for further analysis (see section V). Starting from the full Sample, I require that the firm's earnings forecasts be available in the I/B/E/S database, and that its accounting information be available on the merged quarterly COMPUSTAT database. These data constraints ensure the availability of basic financial information for each firm in my sample. A firm-quarter observation is included in my final sample only if all the variables are available for that quarter.

In the further analysis, I conduct separate tests of how analysts project target prices and issue stock recommendations based on the set of eleven investment signals. Consistent with JKKL, I perform these tests using analyst target prices and stock recommendations as of the last month in each calendar quarter. I truncate each of the predictor variables at the 1 and 99 percentiles to control for outliers. This reduces my sample to 76540 firm-quarter observations over the 40 calendar quarters from 2000 to 2009.

\subsection{Descriptive Statistics}

Table 1, Panel A and Panel B present descriptive statistics on the number of observations by year and exchange respectively. Panel A shows that the average number of firm observations remains rather stable over time from 2000 through 2009. The average firm observations per quarter over the sample period (40 quarters) is approximately 2731. Panel A also reports mean ratio of target price to price (converted to the monthly basis) and mean analyst recommendation for each year from 2000 to 2009. From 2000 and 2009, I observe a decline in the average analyst recommendation in years 2000 through 2003 with the level at 4.0, 3.95. 3.8 and 3.57 respectively. Afterwards, the average analyst recommendation remains stable at around 3.65. The mean ratio of target price to price exhibits a similar pattern in the year 2000 through 2003 with the monthly expected return declines from $3.37 \%$ in 2000 to $1.28 \%$ in 2003. After 2003, however, the ratio fluctuates much more than its corresponding recommendation level. Panel B shows that approximately 51.5 of my observations are Nasdaq (NYSE/AMEX) firms.

Table 2, Panel A presents descriptive statistics for the mean recommendations, the mean ratio of target price to price (converted to the monthly basis) and the mean estimates of the benchmark return used in my analysis. The average monthly return expected by analysts is 1.96 percent, while the estimated from the CAPM, Fama and French (1993) 3 -factor model and Carhart (1997) 4-factor model is 1.57 percent, 2.1 percent and 1.89 percent respectively. Panel B presents mean values for each of the eleven mispricing variables that will be used in the further analysis (see section 5.3.1). I find that earnings surprise (SUE) has a slightly negative mean. Total accruals (TACCR) are on average positive. I find that firm size (using log transformation) has a mean of approximately 7 (SIZE). The average 
earnings-to-price $(E P)$ is only 0.7 percent and the book-to-market ratio $(B P)$ has a mean of 0.54 . Approximately 0.49 percent of a firm's shares turn over on any given day $(T U R N)$. Realized sales growth $(S G)$ averages 1.17 percent, and analysts' long-term earnings growth forecasts $(L T G)$ average 16.24 percent. Capital Expenditures (CAPEX) average approximately 5.4 percent of assets. Analysts' forecast revisions (FREVS) have a mean of approximately zero. Price momentum (PRET) averages 6.2 percent for the preceding six months.

\section{Empirical Results}

\subsection{Contingency Tests and Results}

Contingency tables are constructed to test my hypothesis. I predict that when the ratio of target price to price exceeds the market assessment of return, analysts will be more likely to issue a "buy" recommendation. I construct contingency tables in two different ways.

First, each firm-quarter is assigned to one of two portfolios: Portfolio HIGH or Portfolio LOW. Portfolio HIGH comprises observation for which the ratio of target price to price exceeds the market assessment of return that is generated by the CAPM, Fama French (1993) 3-Factor or Carhart (1997) 4-Factor Model. Portfolio LOW comprises observations for which the ratio of target price to price is lower than the market assessment of return. For brevity, I report results on the CAPM only. Benchmark return based on other two models generates similar inferences.

Second, each firm-quarter is assigned to one of three portfolios: Portfolio POS, Portfolio ZERO or Portfolio NEG. Portfolio POS comprises observation for which the ratio of target price to price exceeds the market assessment of return by $0.05 \%$. Portfolio ZERO comprises observations for which the difference between the ratio of target price to price and benchmark return is between $-0.05 \%$ and $0.05 \%$. Portfolio NEG comprises observations for which the difference between the ratio of target price to price and benchmark return is less than $-0.05 \%$. The reason to construct the contingency table in a more refined way is to separate out the scenario where analysts' estimate of return is very close to the benchmark return.

The incidence of buy and sell recommendation for Portfolio HIGH and Portfolio LOW is presented in the form of a contingency table in Table 3. The row denotes the portfolio to which each firm-quarter is assigned. The column denotes the average analyst recommendation and each cell contains the proportion of observations fulfilling each condition. To classify as a buy, I first convert the mean recommendation to categorical variables. The most highly recommended stocks are those for which the mean recommendation is greater than 3; the second is comprised of firms for which the mean recommendation is between 2.5 and 3; the third contains firms for which the mean recommendation is between 2 and 2.5; the fourth is comprised of firms for which the mean recommendation is between 1.5 and 2; and the fifth consists of the least favorably recommended stocks, those for which the mean recommendation is lower than 2. Therefore, I classify a stock as "buy" if the mean recommendation is greater than 3. The mean recommendations are also displayed for each portfolio. If analysts issue a "buy" recommendation when the ratio of target price exceeds the benchmark return, there will be a higher incidence of buy recommendation and higher mean recommendations for Portfolio High than for Portfolio LOW. The chi-square test is a two-tailed test which compares the number of observation in each contingency table cell with the number expected by chance. The t-tests are two-tailed tests of differences in the mean recommendations for the two portfolios. The construction for Portfolio POS, Portfolio ZERO and Portfolio NEG are similar and therefore omitted for brevity.

Panel A reports results for recommendations with two portfolios. There is a higher proportion of buy recommendations for Portfolio HIGH than for Portfolio LOW, consistent with my prediction. Moreover, the chi-square statistics is statistically significant $\left(\chi_{\mathrm{df}=1}^{2}=388.24 ; \mathrm{p}<0.001\right)$. The mean recommendations support the prediction as well: the mean for Portfolio HIGH is greater than the mean for Portfolio LOW and the t-statistics, comparing the difference in means, is statistically significant $(\mathrm{t}=30.07)$. This result suggests that analysts are likely to issue a more favorable recommendation when the ratio of target price to price exceeds the benchmark return than otherwise.

Panel B reports results for recommendations with more refined three portfolios. Again, the chi-square statistics is statistically significant $\left(\chi_{\mathrm{df}=1}^{2}=407.73 ; \mathrm{p}<0.001\right)$, indicating that there is a greater incidence of buy recommendations when the ratio of target price to price exceeds the benchmark return. Moreover, the incidence of buy recommendations is higher even when the ratio of buy recommendation is fairly close to the benchmark return. Tests of the mean recommendations reinforce the chi-square results: the means for Portfolio POS is greater than the means for Portfolio ZERO, which is greater than the means for Portfolio NEG. The t-tests are both statistically significant at the 0.001 level. These results are consistent with the hypothesis that analysts tend to issue more favorable recommendations when the ratio of target price to price exceeds the benchmark return. 


\subsection{Regression Analysis and Results}

In this section, I perform a regression analysis to test the association between the mean recommendations and the ratio of target price to price. The following regression is estimated for each benchmark return proxy:

$$
R E C=\alpha+\beta \Delta T P P+\varepsilon
$$

where the dependent variable $R E C$ is the mean recommendations. $\triangle T P P$ is defined as the ratio of target price to price minus the benchmark return. I employ three metrics to measure the benchmark: CAPM, 3-Factor and 4-Factor model. I describe the approach in section 2.3. The regressions are estimated using all the full sample data from 2000 through 2009. In all regression analyses, I assess statistical significance using test statistics based on standard errors that are adjusted for two-way clustering of residuals by firm and calendar quarter (Petersen 2009; Gow, Ormazabal and Taylor 2010).

Table 4 reports regression results. I find that for all three benchmark return models I use, the results are broadly consistent with the contingency table analysis. Sample size for all regressions is 109, 230. The second column shows the result when the CAPM model is used as the proxy for the benchmark return. As it can be seen from the table, there is a significant positive coefficient on $\triangle T P P(\beta=0.7705 ; \mathrm{t}=3.13)$, indicating that analysts give more favorable recommendations to stocks when the difference between the ratio of target price to price and the benchmark return is higher. Specifically, for each unite change in $\triangle T P P$, there will be a corresponding 0.77 change in recommendation. The results for other two models (presented in column 3 and 4 in Table 4 respectively) are slightly weaker with the significance at the 0.05 level $(\beta=0.5064 ; \mathrm{t}=2.00 ; \beta=0.5148 ; \mathrm{t}=2.42)$. Overall, the results are consistent with the contingency table analysis as well as the prediction that analyst issue more favorable recommendations to stocks with a higher difference between the ratio of target price to price and the benchmark return.

\section{Further Analysis ------ Risk or Mispricing?}

\subsection{Risk or Mispricing}

There exist at least two interpretations for the positive relationship between the favorableness of stock recommendations and the difference between the ratio of target price to price and the benchmark return. One interpretation is that the ratio of target price to price indicates analysts' perception about the firm risk. When analysts perceive the firm is riskier than what the market perceives to be, they expect a higher return and then are more likely to issue a more favorable recommendation. An alternative interpretation is that the ratio of target price to price reflects analysts' opinion of security mispricing. Therefore a higher (lower) ratio of target price to price may indicate that analysts believe the stock is more likely to be undervalued (overvalued), and hence they issue a more (less) favorable recommendation.

\subsection{Ratio of Target Price to Price and Risk Attributes}

To shed some light on whether the hypothesized relationship is due to risk or mispricing, I examine the extent to which the ratio of target price to price is associated with firm characteristics. I start with risk attributes. If the ratio of target price to price reflects analysts' perception about a firm's risk, then it should be associated with risk factors that have been proposed in prior literature.

Another view posits that the ratio of target price to price reflects the market assessment of risk. For example, using analysts' expected return as unbiased estimates of market-wide expected rates of return, Brav, Lehavy and Michaely (2005) find that there is a positive, robust relation between expected return and market beta and a negative relation between expected return and firm size. They interpret it as evidence that the ratio of target price to price reflect the market assessment of return. If so, then I would expect that there is no relationship between stock recommendations and target prices. Given the evidence I document in section IV, I argue that it is not likely that the ratio of target price to price reflects the market assessment of risk, at least in my research setting (Note 7).

I examine whether the ratio of target price to price is related to factor loadings that have been proposed in the literature. I examine three such asset-pricing model specifications: the CAPM,the Fama and French (1993) 3-factor model and Carhart (1997) 4-factor model (see section 2.3 for a brief review). There are two common approaches to estimate the factor loadings. The first is to use a proxy, such as size and book-to-market, for the factor loadings. The second is to directly estimate the covariance between the factor return and stock return. Since it is not my purpose here to take a stand on which approach is preferred, I simply present the results using both factors and characteristics.

Table 5 Panel A presents the regression results with firms' characteristics as the independent variables. I estimate the one characteristics model using market beta. The results in Panel A, the second column, indicate that the estimate of the annual market premium is positive and highly significant $(\beta=-0.51 ; \mathrm{t}=6.31)$. This evidence shows that analysts' 
expected returns are related to their systematic exposure to the market, and that the relation is both economically and statistically significant.

Next, in the third column I present estimates of coefficients for the Fama and French 3-factor model. I find that the estimate of the market premium drops slightly to 0.447 , but is still highly significant $(\mathrm{t}=5.50)$. The coefficient on size is negative and highly significant $(\beta=-0.0025 ; \mathrm{t}=-10.68)$, suggesting that analysts' expected returns are higher for small firms or equivalently, their risk perception is in line with the market's. The coefficient on book to market ratio is insignificant, inconsistent with the 3 -factor model. However, this result is in line with the survey evidence in Bloomfield and Michaely (2004) regarding analysts' risk perceptions.

The last column of Panel A presents results for the Carhart (1997) 4-factor model where he includes the price momentum as the fourth factor. I find that coefficients on market beta and size are still positive and negative respectively and highly significant. Consistent with results presented above, the coefficient on the book to market ratio is insignificant. The coefficient on the price momentum is negative and highly significant $(\beta=-0.022 ; \mathrm{t}=-10.26)$. This result indicates that analysts do not consider recent winner stocks as riskier and thus do not require higher expected return relative to recent loser stocks. Though this result is inconsistent with what the Carhart (1997) 4-factor model suggests, it is in line with Gebhardt, Lee and Swaminathan (2001) where they find their implied cost of capital estimate is negative associated with the price momentum. Moreover, they argue that this is difficult to explain in a risk context because higher momentum stocks have higher realized return.

Panel A is generally consistent with the results reported by Brav, Lehavy and Michaely (2005). However, they consider the ratio of target price to price as their market assessment return and hence their regression is performed in the asset-pricing context. Therefore, I interpret my results as the analysts' perception of the firm's risk. However, for almost all risk interpretations, there always exists a corresponding mispricing interpretation. Those characteristics exhibiting significance either indicate risk that is perceived by the analysts or indicate mispricing.

The regression analysis using factor loadings presents somewhat different results (Table 5 Panel B). Specifically, there is no significant association between analysts' expected return and firm size when I use $S M B$ as the explanatory variable. There is a positive association between analysts' expected return and price momentum factor, to the contrary of Panel A ( $\beta=0.0008 ; \mathrm{t}=2.5)$. Moreover, in the 4-factor model, the association on book-to-market ratio is no longer insignificant $(\beta=0.0009 ; \mathrm{t}=1.78)$. The only consistent result with Panel $\mathrm{A}$ is the systematic exposure to the market. This inconsistence is puzzling and I leave it to future research.

\subsection{Ratio of Target Price to Price and Mispricing Variables}

The literature has shown analysts' target price forecasts significantly affect stock prices. Combined with the underlying stock price, target price reflects the analyst's beliefs about the firm's expected rate of return. This interpretation suggests a natural link between the literature on analyst price targets and studies on the predictability of cross-sectional returns. As investment professionals, analysts may be explicitly or intuitively aware of the variables that have demonstrated abilities to predict future returns. In this section, I examine the extent to which analysts make full use of available information signals in projecting future returns.

In this respect, this study is closely related to prior studies that investigate whether and to what extent analysts make full use of available information signals in formulating stock recommendations (JKKL, Drake et al. 2011). JKKL find that analysts do not fully take into account the ability of various stock characteristics to predict returns and they generally recommend "glamour" stocks. As a consequence, naïve following analysts' recommendations can be costly. In a similar vein, Drake, Rees and Swanson (2011) examine whether short sellers are able to use investment signals more efficiently. Their evidence suggests that short interest appear to capture predictive information that can be used by investors in trading against analysts' recommendations to increase returns.

My study is different from JKKL and Drake et al. 2011 in the following respects. First, my focus is on analysts' target prices. In contrast, JKKL focus on stock recommendations and Drake et al. 2011 focus on short sellers. Specifically, I examine the source of the investment value provided by analyst target prices. One possible source of this value is the ability of analysts to incorporate firm-specific information into their reports. Second, exploring the link between analysts' target prices and variables that predict future returns could allow a further investigation into how analysts' outputs, specifically, target prices and stock recommendations, are interrelated. In particular, it allows for a direct comparison of information used by analysts to generate target prices and stock recommendations. There is very limited evidence on how these outputs differ in term of the information they convey. To this end, this study sheds light on the interdependencies among different outputs analysts produce. 
Since I adopt a similar framework to JKKL and Drake et al 2011 in examining analysts' target prices, I briefly review these explanatory variables that have demonstrated abilities to predict future returns in the next subsection.

\subsubsection{Factors that predict future returns}

In recent years, a number of researchers have presented evidence that cross-sectional stock returns are predictable based on some public available information signals. JKKL, in investigating the source of the investment value provided by analyst stock recommendations and changes in recommendations, summarize twelve important variables that have demonstrated abilities to predict future returns in the literature. I briefly describe these variables and their normative predictions with future returns as follows. Combining JKKL and Drake, Rees and Swanson (2011), I group the predictor variables into one of five classifications based on the nature of the variable.

Accounting

Earnings Surprise (SUE). Prior studies show that positive earnings surprises earn higher subsequent return (Bernard and Thomas 1989). I capture earnings surprises with the variable SUE. SUE is the unexpected earnings for the most recent reporting quarter, scaled by its time-series standard deviation over the eight preceding quarters.

Total Accruals $(T A C C R)$. Sloan (1996) finds that firms with more negative total accruals earn higher future returns than firms with higher accruals. One explanation is that the market does not take into account the fact that the accrual-component earnings is less persistent in a timely fashion. I measure the total accruals using the variable TACCR.

\section{Valuation}

Earnings-to-price Ratio (EP) and the Book-to-price Ratio (BP). Notably, Fama and French (1992) show that earnings-to-price and book-to-market ratios are positively related to future returns. Considerable prior research has investigated each of these ratios, and their predictive ability with respect to future returns is well documented.

Growth

Sales Growth $(S G)$. Lakonishok, Shleifer, and Vishny (1994) show that firms with low past sales growth could generate higher subsequent returns. I measure $\mathrm{SG}$ as the one-year growth rate in sales.

Long-term Growth in Earnings (LTG). La Porta (1996) shows that firms with low forecasted long-term earnings growth also generate higher subsequent returns. I measure LTG using analysts' forecasted long-term growth in earnings.

Capital Expenditures (CAPEXQ). Beneish, Lee and Tarpley (2001) show that growth firms with high capital expenditures (CAPEXQ) tend to earn lower subsequent returns. They argue that higher capital expenditure firms are growth firms that tend to overextend themselves.

\section{Momentum and Trading Volume}

Price Momentum (PRET). Jegadeesh and Titman (1993) show that firms with higher price momentum tend to earn higher subsequent returns. I capture the price moment effect with the variable PRET, measured as the cumulative market-adjusted returns for each stock in months -6 through -1 preceding the last month of the calendar quarter.

Earnings Momentum (FREVS). Chan, Jagadeesh, and Lakonishok (1996) show that firms with upward revisions in earnings can earn higher future returns. I capture the earnings momentum effect with the variable FREV, measured as a rolling sum of the analyst earnings forecast revision over the six months prior to the last month of the calendar quarter scaled by price.

Trading Volume (TURN). Lee and Swaminathan (2000) show that high trading volume stocks tend to earn lower returns in subsequent months. I measure TURN as the average daily volume turnover for the stock in the six months preceding the last month of the calendar quarter.

Size

Market Value of Equity (SIZE). Banz (1981) shows that small firms earn higher subsequent returns than large firms. However, opinions differ in terms of the interpretation of this variable. Therefore, I include it as a control. In this study, I measure SIZE as the natural log of a firm's market capitalization at the end of its most recent fiscal quarter.

\subsubsection{Results}

Using eleven predictive variables that have demonstrated abilities to predict cross-sectional returns in prior studies, JKKL find that analysts do not fully take into account the ability of various stock characteristics to predict returns and they generally recommend "glamour" stocks. Following JKKL's approach, I examine the extent to which the 
ratio of target price to price incorporates these mispricing variables. More to the point of this study, I conduct JKKL's analysis to allow for a direct comparison of information used by analysts to project target prices and generate stock recommendations.

I group the predictor variables into one of five classifications based on the nature of the variable. The first group, labeled Accounting, consists of earnings surprise (SUE) and total accruals (TACCR). The Valuation group consists of earnings-to-price ratio $(E P)$ and book-to-market ratio $(B P)$. The Growth group consists of sales growth $(S G)$, forecasted long-term earnings growth ( $L T G)$, and capital expenditure (CAPEXQ). The forth group, Momentum and Trading Volume, consist of earnings forecast revision (FREVS), price momentum (PRET) and the average daily stock turnover $(T U R N)$. Finally, I include SIZE as the control variable. These variables have been demonstrated in prior research to be associated with future returns.

The results are shown in Table 6. The second column summarizes the normative prediction based on prior literature (see section 5.3.1 for a review). The third column presents the regression analysis when the ratio of target price to price is the dependent variable and the last column replicates JKKL's analysis.

For the ratio of target price to price, I find that analysts fail to incorporate the implications for future returns of both accounting variables: unexpected earnings (SUE) and total accruals (TACCR), despite evidence that increases in those accounting measures are associated with abnormal future returns. Examining the valuation measures, analysts correctly expect higher returns for firms with higher book-to-market ratio (BP). However, they also expect higher returns for firms with a low earnings-to-price ratio (EP), despite evidence that stock prices of such firms underperform the market. Examining the growth variables, I find that analysts expect higher returns for growth firms with higher sales growth (SG), higher long-term growth (LTG) and higher capital expenditures (CAPEXQ). These growth variables have been documented in prior literature that they are associated with lower abnormal future returns. For the momentum and trading volume variables, analysts expect higher returns for firms with low stock price momentum (PRET) and higher trading volumes (TURN). Finally, analysts expect higher returns for smaller firms (SIZE).

For the recommendation level, I find that analysts favorable recommend firms with high total accruals (TACCR), despite evidence that high accruals are associated with lower future returns. Analysts also correctly favor firms with a higher earnings-to-price ratio (EP). However, they also favor firms with a low book-to-market ratio (BP). Moreover, they favor firms with higher growth variables: sales growth (SG), long-term growth (LTG), and capital expenditures (CAPEX). Finally, analysts correctly favor firms with high earnings momentum (FREVS), high stock momentum (PRET), low trading volume (TURN) and small size (SIZE). These results are broadly consistent with JKKL.

Since stock recommendation reflects opinions on the relative degree of mispricing (Womack 1996), the study by JKKL serves as a natural benchmark for the comparison. I find that both target prices and stock recommendations seem to favor growth ("glamour") stocks despite their well documented negative association with future returns. The coefficients on three growth variables: sales growth $(S G)$, long-term growth $(L T G)$ and capital expenditure $(C A P E X Q)$ are all positive and statistically significant. Since growth variables are widely considered as market anomaly (La Porta 1996), this evidence suggests that the ratio of target price to price might reflect some dimensions of mispricing as well.

However, they do not agree in all aspects. Specifically, for some valuation signals, price momentum and trading volume variables, target prices and stock recommendations appear to incorporate them in completely opposite directions. This finding suggests that although intuitively target prices should be highly associated with stock recommendations, they likely provide different information to investors. Therefore, I am not able to rule out the possibility that the ratio of target price to price also reflects some dimensions of risk.

\subsection{Robustness Check}

The analysis in section 5.2 raises the concern of correlated omitted variable problems. The positive association between the deviation of the ratio of target price to price from the market assessment of return and stock recommendations might be driven by some other common factors. To alleviate this endogeneity problem, I include all the eleven variables in the regression. The results are presented in Table 7. I find that the difference between the ratio of target price to price and the market assessment of return continues to explain the stock recommendations. For all three benchmark models I employ, the coefficients on $\triangle T P P$ are all positive and statistically significant. 


\section{Conclusion}

Using a simple framework, I develop the link between analysts' target prices and stock recommendations. Prior literature provides very little evidence on this issue. Since the ratio of target price to price can be interpreted as analysts' expected return of the firm, I hypothesize that the favorableness of stock recommendations is positively associated with the deviation of the ratio of target price to price and the benchmark return. I use three widely used models to proxy for the benchmark return: CAPM, Fama and French (1993) 3-Factor Model and Carhart (1997) 4-Factor Model. I find results consistent with my hypothesis. Both contingency table and regression analysis support the prediction that analyst issue more favorable recommendations to stocks with a higher difference between the ratio of target price to price and the benchmark return.

This positive association is subject to two different interpretations. One is the risk explanation. Analysts perceive the firm to be riskier and therefore expect a higher rate of return. Correspondingly, they issue a more favorable recommendation. Alternative interpretation is that analysts believe that firms with certain characteristics are undervalued (overvalued), and they issue buy (sell) recommendation accordingly.

To shed light on whether risk or mispricing constitutes the major force underlying the link between target price and stock recommendation, I examine how analysts incorporate firm characteristics into their target price projection and stock recommendation respectively. I use eleven predictive variables that have demonstrated ability in prior literature to predict future returns. A frequent criticism of research documenting a delayed reaction to information is that relation between information and future returns found to exist in the past may not occur in the future. My approach avoids this criticism by comparing how analysts incorporate same information signals in producing different outputs.

I find that both target prices and stock recommendations seem to favor growth ("glamour") stocks despite their well documented negative association with future returns. The coefficients on three growth variables: sales growth $(S G)$, long-term growth $(L T G)$ and capital expenditure $(C A P E X Q)$ are all positive and statistically significant. Since growth variables are widely considered as market anomaly (La Porta 1996), this evidence suggests that the ratio of target price to price might reflect some dimensions of mispricing as well.

However, they do not agree in all aspects. Specifically, for some valuation signals, price momentum and trading volume variables, target prices and stock recommendations appear to incorporate them in completely opposite directions. This finding suggests that although intuitively target prices should be highly associated with stock recommendations, they likely provide different information to investors. Therefore, I am not able to rule out the possibility that the ratio of target price to price also reflects some dimensions of risk. This is also one limitation of this study.

\section{References}

Asquith, P., Mikhail, M. (2005). Information content of equity analyst reports. Journal of Financial Economics. 75, 245-282. http://dx.doi.org/10.1016/j.fineco.2004.01.002

Banz, R. (1981). The relationship between returns and market value of common stocks. Journal of Financial Economics. 9, 3-18. http://dx.doi.org/10.1016/0304-405X(81)90018-0

Beneish, D., Lee, C., Tarpley, R. (2001). Contextual fundamental analysis through the prediction of extreme returns. Review of Accounting Studies. 6, 165-189.

Bernard, V., Thomas, J. (1989). Post-earnings-announcement drift: Delayed price response or risk premium? Journal of Accounting Research (Supplement). 27, 1-36. http://dx.doi.org/10.2307/2491062

Bloomfield, R., Michaely, R. (2004). Risk or mispricing? From the mouths of professionals. Financial Management. 33, 61-81. http://www.jstor.org/stable/3666264

Bradshaw, M. (2002). The Use of Target Prices to Justify Sell-Side Analysts' Stock Recommendations. Accounting Horizons. 27-41. http://dx.doi.org/10.2308/acch.2002.16.1.27

Bradshaw, M., Brown, L. (2007). Do sell-side analysts exhibit differential target price forecasting ability? Working Paper.

Brav, A., Lehavy, R. (2003). An empirical analysis of analysts' target prices: short-term informativeness and long-term dynamics. Journal of Finance. 58, 1933-1967.

Brav, A., Lehavy, R., Michaely R. (2005). Using expectations to test asset pricing models. Financial Management (Autumn), 31-64. http://dx.doi.org/10.1111/j.1755-053X.2005.tb00109.x

Carhart, M. (1997). On persistence in mutual fund performance. Journal of Finance. 52, 57-82. 
http://dx.doi.org/10.2307/2329556

Chan, L., Jegadeesh, N., Lakonishok, J. (1996). Momentum Strategy. Journal of Finance. 51, 1681-1713.

Dechow, P., Kothari, S., Watts, R. (1998). The relation between earnings and cash flows. Journal of Accounting and Economics. 25, 133-168.

Drake M., Rees, L., Swanson, E. (2011). Should investors follow the prophets or the bears? Evidence on the use of public information by analysts and short sellers. The Accounting Review. 86, 101-130. http://dx.doi.org/10.2308/accr.00000006

Fama, E., French, K. (1992). The cross-section of expected stock returns. Journal of Finance. 47, 427-465. http://dx.doi.org/10.1016/S0165-4101(98)00020-2

Fama, E., French, K. (1993). Common risk factors in the returns on bonds and stocks. Journal of Financial Economics. 33, 3-53. http://dx.doi.org/10.1016/0304-405x(93)90023-5

Gleason, C., Johnson, B., Li, H. (2012). Valuation Model Use and the Price Target Performance of Sell-Side Equity Analysts. Contemporary Accounting Research (forthcoming). http://dx.doi.org/10.1111/j.1911-3846.2011.01142.x

Gow, I., Ormazabal, G., Taylor, D. (2010). Correcting for cross-sectional and time-series dependence in accounting research. The Accounting Review. 85, 483-512. http://dx.doi.org/10.2308/accr.2010.85.2.483

Jegadeesh, N., Kim, J., Krische, S., Lee, C. (2004). Analyzing the analyst: When do recommendations add value? Journal of Finance. 3, 1083-1124. http://dx.doi.org/10.1111/j.1540-6261.2004.00657.x

Jegadeesh, N., Titman, S. (1993). Returns to buying winners and selling losers: Implications for stock market efficiency. Journal of Finance. 49, 1541-1578. http://dx.doi.org/10.1111/j.1540-6261.1993.tb04702.x

La Porta, R. (1996). Expectations and the cross-section of stock returns. Journal of Finance. 51, 1715-1742. http://www.jstor.org/stable/2329535?origin=JSTOR-pdf

Lakonishok, J., Shleifer, A., Vishny, R. (1994). Contrarian investment, extrapolation, and risk. Journal of Finance. 49, 1541-1578. http://dx.doi.org/10.1111/j.1540-6261.1994.tb04772.x

Lee, C., Swaminathan B. (2000). Price momentum and trading volume. Journal of Finance. 55, 2017-1070. http://dx.doi.org/10.1111/0022-1082.00280

Lintner, J. (1965). The valuation of risk assets and the selection of risky investments in stock portfolios and capital budgets. Review of Economics and Statistics. 47, 13-37. http://dx.doi.org/10.2307/1924119

Petersen, M. (2009). Estimating standard errors in finance panel data sets: Comparing approaches. The Review of Financial Studies. 22, 435-480. http://di.doi.org/10.1093/rfs/hhn053

Schipper, K. (1991). Analysts' forecasts. Accounting Horizons. 5, 105-121.

Sharpe, W. (1964). Capital asset prices: A theory of market equilibrium under conditions of risk. Journal of Finance. 19, 425-442. http://dx.doi.org/10.2307/2977928

Sloan, R. (1996). Do stocks prices fully reflect information in accruals and cash flows about future earnings? The Accounting Review. 71, 289-315. http://www.jstor.org/stable/248290

Womack, K. (1996). Do brokerage analysts' recommendations have investment value? The Journal of Finance. 51, 137-167. http://dx.doi.org/10.2307/2329305

\section{Notes}

Note 1. The regression using factor loadings provide somewhat mixing results. This inconsistence is puzzling and I leave it to future research.

Note 2. I do not assume any specific model that analysts might adopt because it is not necessary for my analysis. I only require that the estimated firm value is a function of information signals.

Note 3. I restrict my analysis to 12 -month target prices, which constitute more than $90 \%$ of the entire database.

Note 4. Here, I abstract from the manner in which the investors actually derive the necessary knowledge regarding the underlying economy to form these expectations.

Note 5. Note that this algorithm does not consider the incentive problem that analysts might deal with.

Note 6. The construction of SMB and HML portfolios are discussed in Fama and French (1993) and factors are available from French's website. I follow Carhart (1997) and construct MOM as the equal-weighted average of firms 
with the highest 30 percent eleven-month returns lagged one month minus the equal-weighted average of firms with the lowest 30 percent eleven-month returns lagged one month. The portfolios include all NYSE, Amex and Nasdaq stocks and are re-formed monthly.

Note 7. Brav, Lehavy and Michaely (2005) implicitly assume market efficiency. This study differs from theirs in the sense that I do not assume market efficiency.

Table 1. Description of Sample Firms

\begin{tabular}{lllll}
\hline Panel A: Sample Distribution across Years & & & \\
\hline Year & Observations & \% of total & Mean & Mean \\
& Per Quarter & & 3.37 & Recommendation \\
\hline 2000 & 2227 & 8.15 & 3.02 & 4.02 \\
2001 & 2223 & 8.14 & 2.69 & 3.95 \\
2002 & 2367 & 8.67 & 1.28 & 3.80 \\
2003 & 2671 & 9.78 & 1.38 & 3.57 \\
2004 & 2907 & 10.64 & 1.32 & 3.65 \\
2005 & 3021 & 11.06 & 1.49 & 3.66 \\
2006 & 3121 & 11.43 & 1.67 & 3.66 \\
2007 & 3150 & 11.53 & 2.61 & 3.66 \\
2008 & 2728 & 9.99 & 1.60 & 3.68 \\
2009 & 2895 & 10.60 & 1.96 & 3.62 \\
Sample Average & 2731 & & & 3.71 \\
\hline Panel B: Sample Distribution across Exchanges & & Mean \% of Sample \\
\hline Exchange & Mean Observation & Per Quarter & \\
& Per Quarter & & 46.8 & \\
\hline NYSE & 1299 & 51.5 & \\
Nasdaq & 1385 & 1.7 & $100.0 \%$ \\
Amex & 47 & & & \\
Mean Quarterly Sample & 2731 & & & \\
\hline
\end{tabular}

This table provides description of the firms included in my sample. My sample consists of all firms with current individual stock recommendations and target prices in the First Call database. Panel A reports the mean number of observations per quarter for each individual calendar year, the average ratio of target price to price (converted to the monthly return percentage) and the average level of consensus recommendation. I reverse-score the recommendations from five (strong buy) to one (strong sell). For each calendar quarter, I obtain the level of consensus recommendation issued in the most recent month. Panel B reports the sample distribution across exchanges. The sample period is from 2000Q1 through 2009Q4. 
Table 2. Descriptive Statistics

\begin{tabular}{|c|c|c|c|c|}
\hline \multicolumn{5}{|c|}{ Panel A: Summary Statistics for REC, TPP and Cost of Capital Estimate } \\
\hline Variable & Mean & Std Dev & Min & Max \\
\hline$R E C$ & 3.71 & 0.61 & 1 & 5 \\
\hline$T P P$ & 1.96 & 2.68 & -17.4 & 28.3 \\
\hline$C A P M$ & 1.57 & 5.49 & -19.9 & 38.6 \\
\hline FACTOR3 & 2.1 & 6.38 & -19.7 & 39.8 \\
\hline FACTOR4 & 1.89 & 6.90 & -19.9 & 39.9 \\
\hline \multicolumn{5}{|c|}{ Panel B: Summary Statistics for anomaly variables } \\
\hline PRET & 0.062 & 0.343 & -0.749 & 3.471 \\
\hline FREVS & -0.000 & 0.015 & -0.260 & 1.096 \\
\hline$T A C C R$ & 0.007 & 0.082 & -1.671 & 1.470 \\
\hline SUE & -0.003 & 0.128 & -3.102 & 12.62 \\
\hline TURN & 49.44 & 28.79 & 0 & 99 \\
\hline SIZE & 7.079 & 1.673 & 1.167 & 13.31 \\
\hline$E P$ & 0.007 & -0.274 & -13.790 & 1.332 \\
\hline$B P$ & 0.545 & 0.476 & 0.000 & 22.84 \\
\hline CAPEXQ & 0.0550 & 0.070 & 0 & 1.129 \\
\hline$S G$ & 1.179 & 0.790 & 0.253 & 95.52 \\
\hline$L T G$ & 16.25 & 9.564 & -14.5 & 291 \\
\hline
\end{tabular}

Panel A consists of 109,230 firm-quarter observations during the period 2000-2009. REC is the consensus analyst recommendation in the last month of the calendar quarter, where $5=$ strong buy, $4=$ buy, $3=$ hold, $2=$ sell, and $1=$ strong sell. TPP is the ratio of mean consensus target price (issued in the last month of the calendar quarter) to the current stock price converted to the monthly basis. I delete observations if the current stock price is less than \$1. CAPM is the monthly market equilibrium return based on the 1 factor model. FACTOR3 is the monthly market equilibrium return based on the Fama and French (1993) 3-factor model. FACTOR4 is the monthly market equilibrium return based on the Carhart (1997) 4-factor model. Panel B consists of 76,540 firm-quarter observations with the available COMPUSTAT, CRSP and I/B/E/S data. PRET is price momentum, measured as the six-month raw return ending one month prior to the end of the fiscal quarter $q$. FREVS is the rolling sum of the preceding six-month earnings forecast revisions scaled by price. TACCR is total accruals scaled by average assets measured at the end of fiscal quarter $q$. SUE is the seasonally-adjusted earnings change scaled by price for fiscal quarter $q$. TURN is the average daily volume per share over the preceding six months. SIZE is the log of the market value of equity at the end of fiscal quarter $q$. EP is the ratio of the rolling sum of earnings over the preceding four quarters to price at the end of fiscal quarter $q$. BP is the ratio of book value of equity to market value of equity as of the end of fiscal quarter $q$. CAPEXQ is the rolling sum of the preceding four quarters of capital expenditures ending at fiscal quarter $q$ divided by total assets. SG is the rolling sum of sales growth over the preceding four fiscal quarters. LTG is the mean consensus long-term earnings growth forecast at the end of calendar quarter $t$. 
Table 3. Contingency Table

\begin{tabular}{|c|c|c|c|c|c|}
\hline Portfolio $^{a}$ & Buy & Sell & $\begin{array}{l}\text { Number of } \\
\text { Firm-Quarters }\end{array}$ & $\begin{array}{l}\text { Mean } \\
\text { Recommendation }\end{array}$ & $\begin{array}{l}\text { t-test } \\
\text { difference } \\
\text { mean }^{c}\end{array}$ \\
\hline \multicolumn{6}{|l|}{ Panel A } \\
\hline Portfolio HIGH & 0.85 & 0.15 & 48,719 & 3.78 & \multirow{3}{*}{$30.65^{* * *}$} \\
\hline Portfolio LOW & 0.81 & 0.19 & 60,511 & 3.66 & \\
\hline$\chi^{2}(\mathrm{df}=1)^{\mathrm{b}}$ & \multicolumn{4}{|c|}{$388.24^{* * *}$} & \\
\hline \multicolumn{6}{|l|}{ Panel B } \\
\hline Portfolio POS & 0.85 & 0.15 & 48,123 & 3.66 & \multirow{4}{*}{$\begin{array}{l}3.71^{* * *} \\
11.21^{* * *}\end{array}$} \\
\hline Portfolio ZERO & 0.83 & 0.17 & 6,662 & 3.69 & \\
\hline Portfolio NEG & 0.81 & 0.19 & 54,445 & 3.78 & \\
\hline$\chi^{2}(\mathrm{df}=2)$ & \multicolumn{2}{|c|}{$407.73^{* * *}$} & & & \\
\hline
\end{tabular}

${ }^{\text {a }}$ Portfolio HIGH comprises firm-quarters when the ratio of target price to price is greater or equal to CAPM based return. Portfolio LOW comprises firm-quarters when the ratio of target price to price is lower than CAPM based return. Portfolio POS comprises firm-quarters when the difference between the ratio of target price to price and CAPM based return exceeds $0.05 \%$. Portfolio ZERO comprises firm-quarters when the difference between the ratio of target price to price and CAPM based return is between $-0.05 \%$ and $0.05 \%$. Portfolio NEG comprises firm-quarters when the difference between the ratio of target price to price and CAPM based return is lower than $-0.05 \%$. I indicate two-sided statistical difference at $1 \%, 5 \%$, and $10 \%$ as $* * *, * *$, and * respectively.

$\mathrm{b}$ The chi-square test assumes that the sample is a random one from the population, and the sample size is large. The statistics is drawn from a chi-square distribution with $(R-1)(C-1)$ degrees of freedom, where $R$ is the number of rows and $C$ the number of columns in the contingency table.

${ }^{\mathrm{c}}$ This statistical test assumes that the populations are normal with unequal variances.

Table 4. Regression Analysis

\begin{tabular}{llll}
\hline REC & CAPM Model & 3-Factor Model & 4-Factor Model \\
\hline$\Delta$ TPP & $0.7705^{* * *}$ & $0.5064^{* *}$ & $0.5148^{* *}$ \\
& $(3.13)$ & $(2.00)$ & $(2.42)$ \\
R - squared & 0.0043 & 0.003 & 0.0033 \\
\hline
\end{tabular}

$\triangle T P P$ is defined as the difference between the ratio of target price to price (converted to the monthly basis) and CAPM return, 3-Factor return, and 4-factor return respectively. I indicate two-sided statistical difference at $1 \%$, 5\%, and $10 \%$ as $* * * * *$, and $*$ respectively. Standard error is clustered at the firm and quarter level. 
Table 5. Regression of the Ratio of Target Price to price on Risk Attributes

Panel A: Regression of the ratio of Target Price to Price on Firm Characteristics

\begin{tabular}{llll}
\hline & CAPM & 3-Factor Model & 4-Factor Model \\
\hline$\beta$ & $0.511^{* * *}$ & $0.446^{* * *}$ & $0.443^{* * *}$ \\
\multirow{2}{*}{ Size } & $(6.31)$ & $(5.50)$ & $(7.29)$ \\
& & $-0.0026^{* * *}$ & $-0.0029^{* * *}$ \\
BP & & $(-10.68)$ & $(-11.42)$ \\
& & $(-0.002)$ & $(0.001)$ \\
PRET & $(-0.12)$ & $(0.90)$ \\
& & & $-0.0223^{* * *}$ \\
& & & $(-10.26)$ \\
Adj. $\mathrm{R}^{2}$ & & & 0.18 \\
\hline
\end{tabular}

Panel B: Regression of the ratio of Target Price to Price on Factor Loadings

\begin{tabular}{llll}
\hline & CAPM & 3-Factor Model & 4-Factor Model \\
\hline$\beta$ & $0.511^{* * *}$ & $0.523^{* * *}$ & $0.554^{* * *}$ \\
\multirow{2}{*}{ SMB } & $(6.31)$ & $(6.18)$ & $(6.46)$ \\
& & 0.0004 & 0.0002 \\
HML & & $(0.71)$ & $(0.32)$ \\
& & 0.0011 & $0.0009^{*}$ \\
MOM & $(1.41)$ & $(1.78)$ \\
& & & $0.0008^{* *}$ \\
& & & $(2.5)$ \\
Adj. $\mathrm{R}^{2}$ & 0.037 & 0.047 & 0.088 \\
\hline
\end{tabular}

This table presents the regression results of the ratio of target price to price (converted to the monthly basis) on a set of firm characteristics (Panel A) or estimated factor loadings (Panel B).

I indicate two-sided statistical difference at $1 \%, 5 \%$, and $10 \%$ as $* * *, * *$, and $*$ respectively. Standard error is clustered at the firm and quarter level. 
Table 6. Regression of Target Prices and Recommendations on Mispricing Variables

\begin{tabular}{|c|c|c|c|}
\hline Variable & $\begin{array}{l}\text { Normative } \\
\text { Prediction }\end{array}$ & TPP & REC \\
\hline \multicolumn{4}{|c|}{ Accounting } \\
\hline \multirow[t]{2}{*}{ SUE } & + & -0.0006 & -0.014 \\
\hline & & $(-0.45)$ & $(-0.36)$ \\
\hline \multirow[t]{2}{*}{ TACCR } & - & -0.0 .006 & $0.239^{* * *}$ \\
\hline & & $(-1.22)$ & $(2.89)$ \\
\hline \multicolumn{4}{|l|}{ Valuation } \\
\hline \multirow[t]{2}{*}{ EP } & + & $-0.0057^{* * *}$ & $0.159^{* * *}$ \\
\hline & & $(-2.65)$ & $(4.64)$ \\
\hline \multirow[t]{2}{*}{ BP } & + & $0.004^{* * *}$ & $-0.147^{* * *}$ \\
\hline & & $(3.17)$ & $(-7.24)$ \\
\hline \multicolumn{4}{|l|}{ Growth } \\
\hline \multirow[t]{2}{*}{ SG } & - & $0.0008^{* *}$ & $0.033^{* * *}$ \\
\hline & & $(2.31)$ & $(3.46)$ \\
\hline \multirow[t]{2}{*}{ LTG } & - & $0.0006^{* * *}$ & $0.0141^{* * *}$ \\
\hline & & $(11.58)$ & $(16.01)$ \\
\hline \multirow[t]{2}{*}{ CAPEXQ } & - & $0.02^{* * *}$ & $0.496^{* * *}$ \\
\hline & & $(4.83)$ & $(6.42)$ \\
\hline \multicolumn{4}{|c|}{ Momentum and Trading Volume } \\
\hline \multirow[t]{2}{*}{ PRET } & + & $-0.024^{* * *}$ & $0.216^{* * *}$ \\
\hline & & $(-10.14)$ & $(8.17)$ \\
\hline \multirow[t]{2}{*}{ FREVS } & + & 0.034 & $1.603^{* * *}$ \\
\hline & & $(1.43)$ & $(4.05)$ \\
\hline \multirow[t]{2}{*}{ TURN } & - & $0.00002^{* *}$ & $-0.0008^{* * *}$ \\
\hline & & $(2.26)$ & $(-3.53)$ \\
\hline \multicolumn{4}{|l|}{ Control } \\
\hline \multirow[t]{2}{*}{ SIZE } & - & $-0.002^{* * *}$ & $-0.017^{* * *}$ \\
\hline & & $(-9.92)$ & $(-3.54)$ \\
\hline $\operatorname{Adj} R^{2}$ & & 0.2294 & 0.1301 \\
\hline
\end{tabular}

I indicate two-sided statistical difference at $1 \%, 5 \%$, and $10 \%$ as $* * *, * *$, and $*$ respectively. Standard error is clustered at the firm and quarter level. 
Table 7. Robustness Check

\begin{tabular}{|c|c|c|c|}
\hline REC & CAMP & 3-Factor Model & 4-Factor Model \\
\hline \multirow[t]{2}{*}{$\triangle \mathrm{TPP}$} & $0.627^{* * *}$ & $0.402^{*}$ & $0.431^{* *}$ \\
\hline & $(2.82)$ & $(1.96)$ & $(2.43)$ \\
\hline \multirow[t]{2}{*}{ SUE } & -0.010 & -0.011 & -0.013 \\
\hline & $(-0.25)$ & $(-0.29)$ & $(-0.34)$ \\
\hline \multirow[t]{2}{*}{ TACCR } & $0.227^{* * *}$ & $0.222^{* * *}$ & $0.221^{* * *}$ \\
\hline & $(3.06)$ & $(2.89)$ & $(2.91)$ \\
\hline \multirow[t]{2}{*}{ EP } & $0.157^{* * *}$ & $0.158^{* * *}$ & $0.158^{* * *}$ \\
\hline & (4.44) & $(4.50)$ & $(4.55)$ \\
\hline \multirow[t]{2}{*}{ BP } & $-0.154^{* * *}$ & $-0.150^{* * *}$ & $-0.150^{* * *}$ \\
\hline & $(-6.94)$ & $(-6.95)$ & $(-6.93)$ \\
\hline \multirow[t]{2}{*}{ SG } & $0.033^{* * *}$ & $0.033^{* * *}$ & $0.033^{* * *}$ \\
\hline & $(3.40)$ & $(3.47)$ & $(3.46)$ \\
\hline \multirow[t]{2}{*}{ LTG } & $0.0137^{* * *}$ & $0.0139^{* * *}$ & $0.0141^{* * *}$ \\
\hline & (15.04) & (15.68) & (15.79) \\
\hline \multirow[t]{2}{*}{ CAPEXQ } & $0.480^{* * *}$ & $0.487^{* * *}$ & $0.496^{* * *}$ \\
\hline & $(6.10)$ & $(6.20)$ & $(6.42)$ \\
\hline \multirow[t]{2}{*}{ PRET } & $0.239^{* * *}$ & $0.229^{* * *}$ & $0.232^{* * *}$ \\
\hline & $(8.81)$ & $(8.23)$ & $(8.40)$ \\
\hline \multirow[t]{2}{*}{ FREVS } & $1.53^{* * *}$ & $1.56^{* * *}$ & $1.565^{* * *}$ \\
\hline & $(3.80)$ & $(3.87)$ & $(3.89)$ \\
\hline \multirow[t]{2}{*}{ TURN } & $0.00002^{* *}$ & $0.00002^{* *}$ & $-0.0008^{* * *}$ \\
\hline & $(-3.11)$ & $(-3.26)$ & $(-3.26)$ \\
\hline \multirow[t]{2}{*}{ SIZE } & $-0.017^{* * *}$ & $-0.018^{* * *}$ & $-0.017^{* * *}$ \\
\hline & $(-3.46)$ & $(-3.66)$ & $(-3.61)$ \\
\hline $\operatorname{Adj} R^{2}$ & 0.13 & 0.13 & 0.13 \\
\hline
\end{tabular}

